\section{(6) OPEN ACCESS}

\title{
Hypotension induced by the concomitant use of a calcium-channel blocker and clarithromycin
}

\author{
Sayako Takeuchi, Yuki Kotani, Toshihide Tsujimoto
}

Department of Critical Care Medicine, Japanese Red Cross Society Wakayama Medical Center, Wakayama, Japan

\section{Correspondence to}

Dr Yuki Kotani,

dkivoar287@gmail.com

Accepted 23 December 2016

\section{SUMMARY}

In the elderly, calcium-channel blockers are the first-line treatment for hypertension, and macrolides are commonly prescribed antibiotics. Here we report a 78year-old man taking nifedipine, diltiazem and carvedilol who presented with persistent hypotension and bradycardia after clarithromycin was prescribed. He was diagnosed with drug-induced hypotension and treated with fluid resuscitation and vasoactive agents. His symptoms gradually improved. He was transferred out of the intensive care unit 3 days after hospitalisation. Combining calcium-channel blockers and clarithromycin can cause vasodilatory hypotension. The concomitant use of calcium-channel blockers and macrolide antibiotics increases the levels of calcium-channel blockers in the blood as they are metabolised by cytochrome P450 3A4 (CYP3A4), which is inhibited by macrolide antibiotics. Moreover, the addition of another calcium-channel blocker and a $\beta$ blocker can lower cardiac output due to bradycardia and worsen hypotension. Therefore, it is important to consider drug interactions when the cause of hypotension is unknown.

\section{BACKGROUND}

Calcium-channel blockers are the first-line treatment for hypertension in the elderly. ${ }^{1}$ Macrolides such as clarithromycin are the most widely prescribed antibiotics to outpatients. ${ }^{2}$ However, it is not widely known that hypotension can be induced by the interaction between these two types of drugs. Here we report a case of hypotension caused by the concomitant use of a calcium-channel blocker and clarithromycin.

\section{CASE PRESENTATION}

A 78-year-old man visited a hospital for cough and sputum, and he was prescribed with clarithromycin. The following day, he was admitted to our hospital due to loss of consciousness. His medical history included hypertension, atrial fibrillation and chronic kidney disease. His baseline blood pressure was $140 / 60 \mathrm{~mm} \mathrm{Hg}$. He reportedly took two calcium-channel blockers, nifedipine and diltiazem, as well as carvedilol, and a few other drugs (irbesartan, azosemide, warfarin, ranitidine, sitagliptin, sodium ferrous citrate, isosorbide dinitrate and dypiridamole). His Glasgow Coma Scale score was 14/15 (E4V4M6). He had a blood pressure of 96/ 38 (mean 57) $\mathrm{mm} \mathrm{Hg}$, pulse rate of $44 \mathrm{bpm}$, respiratory rate of 20 breaths/min, oxygen saturation of $97 \%$ (room air) and temperature of $36.4^{\circ} \mathrm{C}$. Physical examination showed no abnormal findings. The peripheries were warm.

A 12-lead ECG at admission revealed atrial fibrillation with ST-segment depression in V6, and T-wave inversions in I and aVL (figure 1). The corrected QT interval was 360-400 ms. Trunk CT scan showed no abnormal findings. Laboratory data showed leukocytosis $(11400 / \mu \mathrm{L})$ and an elevated creatinine level $(1.95 \mathrm{mg} / \mathrm{dL})$.

\section{DIFFERENTIAL DIAGNOSIS}

The following differential diagnoses were considered: septic shock, cardiogenic shock and
To cite: Takeuchi $S$, Kotani Y, Tsujimoto T. BMJ Case Rep Published online: [please include Day Month Year] doi:10.1136/bcr-2016218388

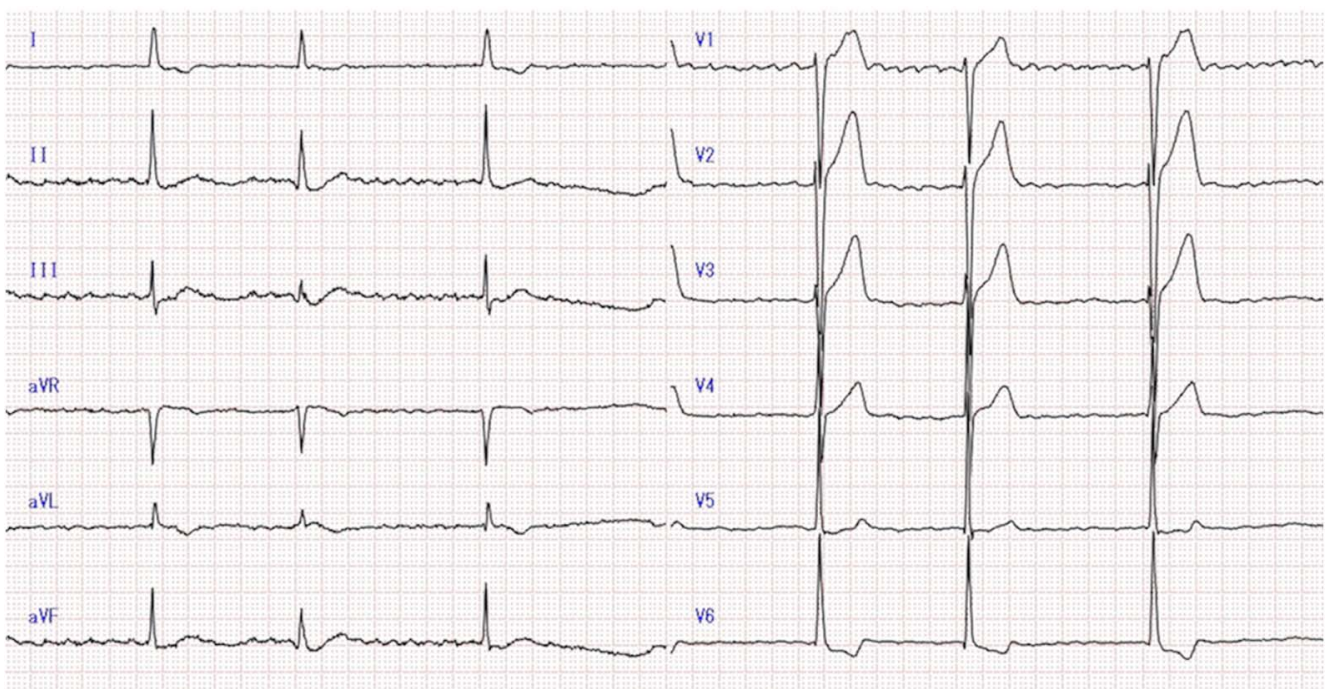

Figure 1 12-Lead electrocardiogram at admission. 
hypovolaemic shock. Septic shock was our initial consideration. However, the patient's respiratory symptoms were mild, and he required no supplemental oxygen. Furthermore, no consolidation was found in his lungs.

Second, we suspected cardiogenic shock. Although his ECG showed atrial fibrillation with bradycardia, a transthoracic echocardiogram revealed normal ventricular wall motion with preserved ejection fraction. Even after his heart rate increased to $70 \mathrm{bpm}$ after atropine administration, his blood pressure showed no improvement (mean arterial pressure was $45 \mathrm{~mm} \mathrm{Hg}$ ).

Third, we suspected hypovolaemic shock. However, his history of present illness and physical examination showed no signs of fluid loss. Furthermore, the administration of intravenous fluids did not improve his blood pressure.

After the other causes of hypotension were ruled out, we attributed his hypotension to a drug interaction between a calcium-channel blocker and clarithromycin.

\section{TREATMENT}

The patient was transferred to the intensive care unit, and all his medications were discontinued. Norepinephrine $(0.1 \mu \mathrm{g} / \mathrm{kg} / \mathrm{min})$ and isoproterenol $(0.008 \mu \mathrm{g} / \mathrm{kg} / \mathrm{min})$ were administered to maintain a mean arterial pressure of $>60 \mathrm{~mm} \mathrm{Hg}$ and a heart rate of $>60 \mathrm{bpm}$. On hospital day 2, norepinephrine was gradually reduced and discontinued. Isoproterenol was still required that morning because his heart rate fell below $50 \mathrm{bpm}$ and an ECG revealed a second-degree atrioventricular block after discontinuation of isoproterenol. In the evening, however, isoproterenol was also discontinued (figure 2). His serum creatinine level gradually recovered $(1.34 \mathrm{mg} / \mathrm{dL}$ on the morning of hospital day 3 ). He remained stable, and on hospital day 3, he was transferred out of the intensive care unit.

\section{OUTCOME AND FOLLOW-UP}

The patient was healthy on review at 2 weeks after discharge.

\section{DISCUSSION}

We realised two important clinical issues through this case. First, the combination of calcium-channel blockers and clarithromycin can cause hypotension because of excessive vasodilation. Second, the addition of another calcium-channel blocker and a $\beta$ blocker can lower cardiac output due to bradycardia and thus worsen hypotension.

To confirm a diagnosis of drug-induced hypotension in this case, it was necessary to rule out other causes of hypotension. In this case, septic shock was first suspected but was excluded because his respiratory symptoms were too mild. Cardiogenic shock was ruled out because the echocardiogram showed
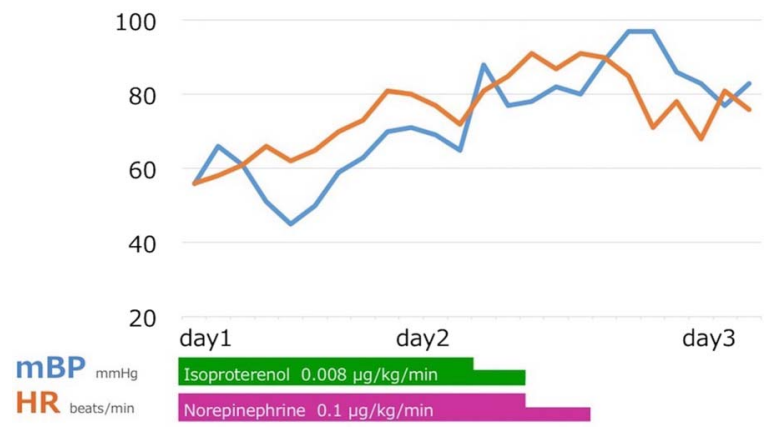

Figure 2 Haemodynamics during ICU stay. normal ventricular wall motion with preserved ejection fraction, and the patient's blood pressure remained low even after his bradycardia improved. Hypovolaemic shock was also ruled out because the administration of intravenous fluids failed to improve his blood pressure.

Calcium-channel blockers are metabolised by the CYP3A4 enzyme, which are inhibited by macrolide antibiotics. Concomitant use of these drugs can result in vasodilatory hypotension. ${ }^{3}$ It is reported that a combination of these drugs increases hospitalisation with hypotension or acute kidney injury. When calcium-channel blockers were used with clarithromycin, 1 in 464 people were hospitalised. One in 160 people were hospitalised when nifedipine, which our patient had been taking, was given along with clarithromycin. This was more frequent than any other calcium blocker. ${ }^{3}$

Vasodilatory shock can worsen with bradycardia caused by other drugs. In this case, hypotension due to a drug interaction occurred the day after the patient began using a combination of calcium-channel blockers and clarithromycin. Previous reports, however, showed that most patients develop clinical symptoms 2-3 days after using this drug combination. ${ }^{4-6}$ The inhibitory effect of a 14-membered ring macrolide, such as clarithromycin and erythromycin, on CYP 3A4 does not occur immediately because these antibiotics need to be metabolised before showing their inhibitory effect. The time difference between our case and previous ones may be due to the influence of diltiazem (benzothiazepine calcium-channel blocker) and carvedilol ( $\beta$ blocker), which the patient was taking in addition to nifedipine. Benzothiazepine calcium-channel blockers have negative inotropic and chronotropic effects and, in excess, can disturb the cardiac conduction system. $\beta$-Blockers prevent the increase in heart rates. ${ }^{7}$ Consequently, these additional effects can lower cardiac output and worsen hypotension.

Since carvedilol is also metabolised by CYP3A4, its plasma concentration could be increased by the inhibitory effect of clarithromycin on CYP3A4.

In conclusion, the combination of calcium-channel blockers and clarithromycin can cause hypotension. Adding another calcium-channel blocker and a $\beta$ blocker can worsen hypotension by inducing bradycardia and reducing cardiac output. Our society is ageing rapidly and more elderly people will require calcium-channel blockers. We need to consider the possibility of a drug interaction in a hypotensive patient when its cause is unknown.

\section{Learning points}

- Hypotension can be induced by the interaction between calcium-channel blockers and clarithromycin, which are widely prescribed drugs.

- Adding another calcium-channel blocker and a $\beta$ blocker can worsen hypotension.

- It is important to consider drug interactions when cause of hypotension is unknown.

Contributors ST and YK wrote and edited the case report. TT had the idea for this case report and was involved in the review.

Competing interests None declared.

Patient consent Obtained. 
Provenance and peer review Not commissioned; externally peer reviewed.

Open Access This is an Open Access article distributed in accordance with the Creative Commons Attribution Non Commercial (CC BY-NC 4.0) license, which permits others to distribute, remix, adapt, build upon this work non-commercially, and license their derivative works on different terms, provided the original work is properly cited and the use is non-commercial. See: http://creativecommons.org/ licenses/by-nc/4.0/

\section{REFERENCES}

1 James PA, Oparil S, Carter BL, et al. 2014 Evidence-based guideline for the management of high blood pressure in adults: report from the panel members appointed to the Eighth Joint National Committee ( JNC 8). JAMA 2014;311:507-20.
2 Hicks LA, Taylor TH Jr, Hunkler RJ. U.S. outpatient antibiotic prescribing, 2010 N Engl J Med 2013;368:1461-2.

3 Gandhi S, Fleet JL, Bailey DG, et al. Calcium-channel blocker-clarithromycin drug interactions and acute kidney injury. JAMA 2013;310:2544-53.

4 Agrawal V, Chaudhari S, Sy A, et al. A case of hypotension and bradycardia precipitated by drug interaction of clarithromycin and calcium-channel blocker. J Am Geriatr Soc 2015;63:1966-7.

5 Reed M, Wall GC, Shah NP, et al. Verapamil toxicity resulting from a probable interaction with telithromycin. Ann Pharmacother 2005;39:357-60.

6 Gerónimo-Pardo M, Cuartero-del-Pozo AB, Jiménez-Vizuete JM, et al.

Clarithromycin-nifedipine interaction as possible cause of vasodilatory shock. Ann Pharmacother 2005;39:538-42.

7 Pearigen PD, Benowitz NL. Poisoning due to calcium antagonists. Experience with verapamil, diltiazem and nifedipine. Drug Safety 1991;6:408-30.

Copyright 2017 BMJ Publishing Group. All rights reserved. For permission to reuse any of this content visit http://group.bmj.com/group/rights-licensing/permissions.

BMJ Case Report Fellows may re-use this article for personal use and teaching without any further permission.

Become a Fellow of BMJ Case Reports today and you can:

- Submit as many cases as you like

- Enjoy fast sympathetic peer review and rapid publication of accepted articles

- Access all the published articles

- Re-use any of the published material for personal use and teaching without further permission

For information on Institutional Fellowships contact consortiasales@bmjgroup.com

Visit casereports.bmj.com for more articles like this and to become a Fellow 